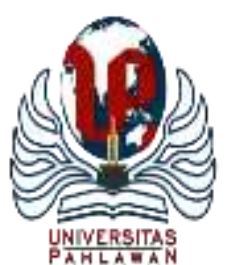

Edukatif : Jurnal Ilmu Pendidikan Volume 3 Nomor 6 Tahun 2021 Halm 5202 - 5212

EDUKATIF: JURNAL ILMU PENDIDIKAN

Research \& Learning in Education

https://edukatif.org/index.php/edukatif/index

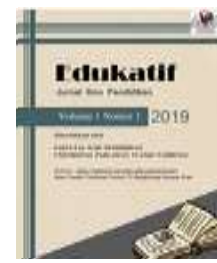

\title{
The Strategy of Observing, Imitation, and Modification in The Preparation of Lesson Plan in Microteaching Practice
}

\author{
Dina Ramadhanti ${ }^{1 凶}$, Diyan Permata Yanda $^{2}$ \\ STKIP PGRI Sumatera Barat, Indonesia ${ }^{1}$ \\ Institut Agama Islam Negeri (IAIN) Bukittinggi, Indonesia ${ }^{2}$ \\ E-mail : dina_ramadhanti89@yahoo.com ${ }^{1}$, diyan_yanda@yahoo.com ${ }^{2}$
}

\begin{abstract}
Abstrak
Rencana pembelajaran menjadi salah satu faktor penentu keberhasilan pelaksanaan pembelajaran. Rencana pembelajaran menjadi bagian utama dalam siklus praktik microteaching. Akan tetapi, dalam praktik microteaching, rencana pembelajaran tidak lebih penting daripada praktik keterampilan dasar mengajar sehingga mahasiswa calon guru tidak terampil dalam menyusun rencana pembelajaran. Dalam penyusunan rencana pembelajaran digunakan strategi observing, imitation, dan modification agar subjek penelitian dapat menyusun rencana pembelajaran sesuai dengan komponen-komponen rencana pembelajaran yang mengintegrasikan keterampilan Abad-21. Penelitian ini merupakan penelitian eksperimen satu kelompok untuk mengetahui perbedaan rata-rata hasil belajar sebelum dan sesudah menggunakan strategi observing, imitation, dan modification. Hasil penelitian menunjukkan bahwa hasil belajar subjek penelitian setelah menggunakan strategi observing, imitation, dan modification lebih baik daripada sebelum menggunakan strategi observing, imitation, dan modification. Strategi ini efektif digunakan karena mampu meningkatkan pemahaman dan kreativitas subjek penelitian terhadap penyusunan rencana pembelajaran. Dalam praktik microteaching, penyusunan rencana pembelajaran perlu menjadi perhatian utama sebelum mahasiswa calon guru mempraktikkan keterampilan dasar mengajar.
\end{abstract}

Kata Kunci: strategi, rencana pembelajaran, pengajaran mikro

\section{Abstract}

The lesson plan is one of the determining factors for the success of the learning implementation. Lesson plans are a major part of the microteaching practice cycle. However, in the practice of microteaching, lesson plans are not more important than the practice of basic teaching skills so that student-teacher is not skilled in preparing lesson plans. In preparing the lesson plans, observing, imitation, and modification strategies are used so that the research subjects can prepare lesson plans according to the components of the lesson plans that integrate 21 st Century skills. This study is a one-group experimental study to determine the difference in average learning outcomes before and after using observing, imitation, and modification strategies. The results showed that the study subjects' learning outcomes after using the observing, imitation, and modification strategies were better than before using the observing, imitation, and modification strategies. This strategy is effectively used because it can increase the understanding and creativity of research subjects in the preparation of lesson plans. In the practice of microteaching, the preparation of lesson plans needs to be a major concern before student teacher candidates practice basic teaching skills.

Keywords: strategy, lesson plan, microteaching

Copyright (c) 2021 Dina Ramadhanti, Diyan Permata Yanda

$\triangle$ Corresponding author:

Email : dina_ramadhanti89@yahoo.com

DOI : https://doi.org/10.31004/edukatif.v3i6.1664

ISSN 2656-8063 (Media Cetak)

ISSN 2656-8071 (Media Online)

Edukatif : Jurnal Ilmu Pendidikan Vol 3 No 6 Tahun 2021 p-ISSN 2656-8063 e-ISSN 2656-8071 
5203 The Strategy of Observing, Imitation, and Modification in The Preparation of Lesson Plan in Microteaching Practice - Dina Ramadhanti, Diyan Permata Yanda

DOI: https://doi.org/10.31004/edukatif.v3i6.1664

\section{INTRODUCTION}

Microteaching has long been used as an efficient training technique for effective teaching (Remesh, 2013). Microteaching is known as a teacher training technique to learn teaching skills and help prospective teachers acquire the art of teaching. In practice, microteaching is proven to have an effect on increasing student-teacher confidence in learning (Bilen, 2015)'(Suryani \& Rismiyanto, 2021)'(d'Alessio, 2018), increase the confidence of prospective teachers so that they are better prepared to teach in real classrooms (Wang, 2021)'(R. Kimaro1, Mhagama, \& Onyango, 2021)'(Iswantir \& Sesmiarni, 2021)'(Kant, 2017), their teaching methods are more varied (Mahmud, 2013), and improve the various teaching skills of student-teacher (Apling \& Haryani, 2019)'(Ramanathan et al., 2021). Through microteaching, student-teachers are trained to use various teaching skills, use learning media, make variations, and provide evaluation and feedback to optimize student learning outcomes (Novrianti, 2016).(Wahyudi \& Sari, 2016). All of this is a provision for studentteachers so that they have pedagogic, personality, social, and professional competencies (Nurdin, 2016).(Hendrizal, Wahyuni, \& Desmariani, 2016). With various benefits obtained by student-teachers, microteaching is a promising innovation in teacher education (Turney, 1970).

Microteaching is basically carried out with a cycle system or also known as the Stanford technique, namely: plan $\rightarrow$ teach $\rightarrow$ observe $\rightarrow$ re-plan $\rightarrow$ re-teach $\rightarrow$ re-observe (Remesh, 2013). Furthermore, microteaching consists of three phases, namely: knowledge acquisition phase, skill acquisition phase (interactive and integration), and transfer phase. In the knowledge acquisition phase, student-teachers receive basic teaching skills training as well as teaching components through lectures, discussions, illustrations, and demonstrations of teaching skills. They also analyze the objective and methodological skills. In the interactive skills acquisition phase, student-teachers practice basic teaching skills. Peers serve as evaluators while learning and modifying their own teaching. In short, in the skills acquisition phase, student-teachers plan lessons, teach or implement skills, conduct evaluation and feedback, and plan and teach back. In the transfer phase, student-teachers who have received basic teaching skills training can apply their knowledge and skills in the real classroom.

One of the most important aspects of microteaching is the lesson plan. Lesson plans need to be structured in a logical order, the content must be concise and organized, precise, relevant, and can cover the time duration specified in the microteaching, usually 36 minutes for the complete duration in the microteaching cycle(Ali, 2021). The lesson plan must be an important place in teacher education because it relates to the professionalism of prospective teachers in carrying out learning.

Research related to microteaching so far has focused more on the practice of microteaching both manually to determine the effect of microteaching on teaching practices and the application of technology in the implementation of microteaching, such as using Moodle and Google Classroom in the implementation of microteaching (Tatminingsih, 2020),(Khikmah, Lovia, Zahro, \& Azizah, 2021). The use of technology in the practice of microteaching based on the results of the study aims to make student-teachers understand and be able to adapt technology in real classroom learning (Akman, 2018).

Research on the preparation of lesson plans in microteaching is rarely studied. In fact, the lesson plan is the main aspect in implementing quality learning (Dorovolomo, Phan, \& Maebuta, 2010). The lesson plans can be thought of as a way to ensure effective classrooms and as a vehicle for professional learning and curriculum development. In short, planning involves a complex combination of knowledge, skills, understanding, values, attitudes, and desires that lead to effective action in the classroom (Munthe \& Conway, 2017).

The lesson plans need to be well planned and need to be adapted to the current situation and conditions, for example, the preparation of lesson plans by integrating 21 st Century skills, namely by incorporating elements of the main character (religious, nationalist, independent, mutual cooperation, and integrity), critical 
5204 The Strategy of Observing, Imitation, and Modification in The Preparation of Lesson Plan in Microteaching Practice - Dina Ramadhanti, Diyan Permata Yanda

DOI: https://doi.org/10.31004/edukatif.v3i6.1664

thinking skills and problem-solving, creativity and innovation, collaboration, and literacy skills (information literacy, media literacy, and information technology literacy) in learning scenarios.

To carry out microteaching, especially in preparing lesson plans, observing, imitation, and modification strategies can be used. This strategy originated from the social learning theory proposed by Albert Bandura in 1977. Bandura said that behavior is learned from the environment through an observational learning process because behavior change occurs through the observation process (Fryling, Johnston, \& Hayes, 2011)'(Greer, Dudek-Singer, \& Gautreaux, 2006). Behavior and environment influence each other in the learning process. In short, people learn through the process of observation, imitation, and modeling (Edinyang, 2016)'(Nabavi, 2012). In its application in the classroom, students observe behavior, assimilate and imitate behavior, take everything positive from the observed behavior and begin to modify it by acting according to experience.

In the preparation of lesson plans, the strategy of observing, imitation, and modification is carried out in three stages, namely: first, the student-teacher observes an example of a 21 st Century lesson plan that has been prepared according to the components of the lesson plan. Second, the student-teacher imitates the example of the lesson plan provided. Third, the student-teacher modify the example and adapt it to the curriculum used and the basic competencies to be taught.

In the preparation of lesson plans, the strategy of observing, imitation, and modification is carried out in three stages, namely: first, the student-teacher observes an example of a 21 st Century lesson plan that has been prepared according to the components of the lesson plan. Second, the student-teacher imitates the example of the lesson plan provided. Third, the student-teacher modify the example and adapt it to the curriculum used and the basic competencies to be taught.

\section{METHOD}

This study is a quantitative study using a pre-experimental method to determine the effect of using observing, imitation, and modification strategies on microteaching, especially in the preparation of lesson plans. The population in this study were students of the 2018 Indonesian Language and Literature Education Study Program who took the Micro Teaching course. The sample in this study amounted to 22 people.

The instrument used in this study was a lesson plan writing task sheet. Data collection techniques were carried out by: (1) giving the task of writing a lesson plan before using the observing, imitation, and modification strategy, (2) carrying out learning using the observing, imitation, and modification strategy in the sub-material for preparing the lesson plan, and (3) providing the task of writing a lesson plan after using the strategy of observing, imitation, and modification. The things assessed include eight things, namely: the completeness of the learning plan components, the ability to formulate indicators of competency achievement, the ability to formulate learning objectives, the ability to formulate subject matter, the ability to choose learning models or methods that are in accordance with learning objectives, the ability to choose media and learning resources, the ability to design learning steps according to learning methods and incorporate elements of 21st Century skills, and the ability to design assessments (Rasmawan, 2021).

Furthermore, data analysis was carried out using SPSS 23. The formula used was the pair-sample t-test formula. After the data was analyzed, a discussion of the findings was carried out.

\section{FINDINGS AND DISCUSSION}

In this section, the results and discussion of the three research problem formulations are described, namely: (1) learning outcomes before using the observing, imitation, and modification strategy, (2) learning outcomes after using the observing, imitation, and modification strategy, and (3) the effect of observing, imitation, and modification strategies on microteaching, especially in preparing lesson plans. 
5205 The Strategy of Observing, Imitation, and Modification in The Preparation of Lesson Plan in Microteaching Practice - Dina Ramadhanti, Diyan Permata Yanda

DOI: https://doi.org/10.31004/edukatif.v3i6.1664

\section{Learning Outcomes Before Using Observing, Imitation, and Modification Strategies}

The results of descriptive statistical tests on learning outcomes data before using the observing, imitation, and modification strategy are presented in Table 1 below.

Table 1

Descriptive Statistical Test of Data Before Using Observing, Imitation, and Modification Strategies

\begin{tabular}{|c|c|}
\hline \multirow{2}{*}{\begin{tabular}{ll}
$\mathrm{N}$ & Valid \\
\cline { 2 - 2 } & Missing \\
\end{tabular}} & Pretest \\
\hline \multirow{2}{*}{\begin{tabular}{ll}
$\mathrm{N}$ & Valid \\
\cline { 2 - 2 } & Missing
\end{tabular}} & 22 \\
\hline & 0 \\
\hline & 75.8636 \\
\hline Std. Error of Mean & 1.30483 \\
\hline Median & 78.0000 \\
\hline Mode & 78.00 \\
\hline Std. Deviation & 6.12019 \\
\hline Variance & 37.457 \\
\hline Skewness & -1.644 \\
\hline Std. Error of Skewness & .491 \\
\hline Kurtosis & 2.679 \\
\hline Std. Error of Kurtosis & .953 \\
\hline Range & 23.00 \\
\hline Minimum & 60.00 \\
\hline Maximum & 83.00 \\
\hline Sum & 1669.00 \\
\hline
\end{tabular}

Based on Table 1 above, the statistical test for learning outcomes data before using the observing, imitation, and modification strategy, namely: the research sample who did the task of preparing the lesson plan was 22 people and no data was lost. The value of the tendency of central data, namely: the mean data is 75.86; the median of data was 78.00; data mode is 78.00; and Sum data is 1669.00. The value of the dispersion (difference) of the data, namely: the minimum score is 60.00; maximum score is 83.00; data range is 23.00; data variance is 37.46; the standard deviation of the data is 6.12; and the standard error of the mean data is 1.30. Based on the data distribution, namely: the value of skewness is -1.644 and the standard error of skewness is 0.491 . The value of the skewness ratio is -3.348 . The value of kurtosis is 2.679 and the standard error of kurtosis is 0.953 . The value of the kurtosis ratio is 2.811 . Based on the value of the skewness ratio and the value of the kurtosis ratio, it is stated that the learning outcomes data before using the observing, imitation, and modification strategy are not normally distributed because the value of the skewness ratio and the value of the kurtosis ratio are outside the range of -2 to 2 .

Before using the strategy of observing, imitation, and modification, learning to prepare lesson plans was carried out by way of assignments. The teacher provides learning modules and assignments through elearning. Student-teacher studies the module on lesson plans and then works on the task of compiling a lesson plan according to the components of the lesson plan contained in the module.

From the results of the data analysis, students teacher's abilities are not evenly distributed. Learning with assignments has not fully influenced the learning outcomes of preparing lesson plans. Of the eight learning plan assessment indicators, not all student-teacher are able to prepare lesson plans well. This is evident from the results of the assessment based on eight assessment indicators, namely: the completeness of the learning plan components, the ability to formulate indicators of competency achievement, the ability to formulate learning objectives, the ability to formulate subject matter, the ability to choose learning models or methods that are in accordance with learning objectives, the ability to choose media and learning resources, the ability to design learning steps according to learning methods and incorporate elements of 21 st Century skills, and the ability to design assessments. 
5206 The Strategy of Observing, Imitation, and Modification in The Preparation of Lesson Plan in Microteaching Practice - Dina Ramadhanti, Diyan Permata Yanda

DOI: https://doi.org/10.31004/edukatif.v3i6.1664

First, the student-teacher is able to present a lesson plan in accordance with the components of the lesson plan as presented in the given module even though the content has not fully met the criteria assessed. Second, the student-teacher is not yet fully able to formulate indicators according to aspects of audience, behavior, condition, and degree. Students-teacher tends to leave the audience and degree aspects in presenting indicators of competency achievement. Third, student-teacher are able to formulate learning objectives. However, they have not included aspects of attitude assessment in formulating learning objectives. Fourth, the student-teacher has not been able to present the subject matter completely and in accordance with the needs of students. Students-teacher also has not presented subject matter for aspects of knowledge and skills as demanded by Curriculum 2013. In terms of knowledge, student-teacher also has not grouped subject matter in terms of factual, conceptual, procedural, and metacognitive. Students-teacher also has not grouped subject matter to be studied in regular, remedial, and enrichment classes. In fact, these are all important components in presenting the subject matter in the 21 st Century RPP. Fifth, student-teacher are able to choose the learning method that will be used in accordance with the learning objectives. However, they have not been able to distinguish between approaches, strategies, techniques, methods, and learning models. Sixth, student-teacher can present learning media and learning resources used. However, the learning resources used are not visible in presenting the subject matter. Supposedly, learning resources used in addition to being used by students to learn are also a source for teachers in presenting subject matter. Seventh, the student-teacher is able to present learning steps according to the learning objectives and learning methods used. However, the components of 21 st Century learning have not been found in the learning steps. Students should be able to adapt the methods used in learning to the 21st Century learning components. Eighth, student-teacher has not been able to present assessments in accordance with the concept of 21st Century learning plans. Students-teacher has not presented an attitude assessment journal to assess student attitudes during learning. Student-teacher has not presented an assessment for the knowledge aspect in the form of multiple-choice tests, essay tests, and so on. Studentteacher has not been able to present assessments for aspects of skills that should be presented in the form of an assessment rubric, both in analytical and holistic forms. In addition, the designed learning plans are also not equipped with teaching materials, assessment journals, and student worksheets.

In general, learning carried out in the form of assignments cannot be fully understood by studentsteacher. Students-teacher who have low reading skills cannot understand the learning modules given well. The learning module will be suitable for those who have a high interest in reading and have good awareness to do the assigned tasks (Ramadhanti, Yanda, Basri, \& Abdurahman, 2020).

\section{Learning Outcomes After Using Observing, Imitation, and Modification Strategies}

The results of descriptive statistical tests on learning outcomes data after using the observing, imitation, and modification strategy are presented in Table 2 below.

Table 2

Descriptive Statistical Test of Data After Using Observing, Imitation, and Modification Strategies Postest

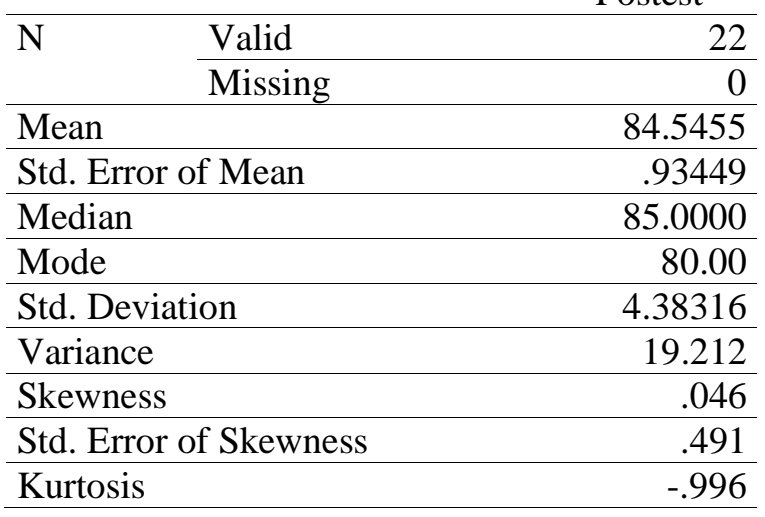


5207 The Strategy of Observing, Imitation, and Modification in The Preparation of Lesson Plan in Microteaching Practice - Dina Ramadhanti, Diyan Permata Yanda

DOI: https://doi.org/10.31004/edukatif.v3i6.1664

\begin{tabular}{lr}
\hline Std. Error of Kurtosis & .953 \\
\hline Range & 15.00 \\
\hline Minimum & 78.00 \\
\hline Maximum & 93.00 \\
\hline Sum & 1860.00 \\
\hline
\end{tabular}

Based on Table 2 above, the statistical test for learning outcomes data after using the observing, imitation, and modification strategy, namely: the research sample who did the task of preparing the lesson plan was 22 people and no data was lost. The value of the tendency of central data, namely: the mean data is 84.55; the median of data was 85.00; data mode is 80.00; and Sum data is 1860.00 . The value of the dispersion (difference) of the data, namely: the minimum score is 78.00; maximum score is 93.00 ; data range is 15.00; data variance is 19.21; the standard deviation of the data is 4.38; and the standard error of the mean data is 0.934. Based on the data distribution, namely: the value of skewness is 0.046 and the standard error of skewness is 0.491 . The value of the skewness ratio is 0.093 . The value of kurtosis is -0.996 and the standard error of kurtosis is 0.953 . The value of the kurtosis ratio is -1.045 . Based on the value of the skewness ratio and the value of the kurtosis ratio, it is stated that the learning outcomes data after using the observing, imitation, and modification strategy are normally distributed because the value of the skewness ratio and the value of the kurtosis ratio are outside the range of -2 to 2 .

Learning using the strategy of observing, imitation, and modification is also carried out through elearning. Besides being given learning modules, examples of 21st Century learning plans are also given. The implementation of learning is carried out in three stages, namely: observing, imitation and modification. In the observing stage, students-teachers observe and study examples of lesson plans that have been designed according to 21st Century skills. In the imitation stage, student-teachers imitate the style of presenting lesson plans that integrate 21 st Century skills into learning scenarios. In the modification stage, student-teachers modify and design learning plans according to the basic competencies selected from the Curriculum 2013, then present them in the form of 21 st Century learning plans equipped with teaching materials, assessment journals (attitudes, knowledge, and skills), and student worksheets.

From the results of data analysis, the strategy of observing, imitation, and modification gave a good influence on student learning outcomes. The ability of student-teachers is evenly distributed and they are able to present 21st Century learning plans well. Although there is still student-teacher who still need improvement, in the general, student-teacher can design lesson plans by integrating 21st Century skill. The 21st Century lesson plan consists of the following components. (1) The identity of the learning plan includes the education unit, subject, class/semester, subject matter, main sub material, and time allocation. (2) Core Competencies include spiritual attitudes, social attitudes, knowledge, and skills. This is clearly stated in the curriculum. (3) Basic Competence and Competency Achievement Indicators. Basic Competencies are also included in the curriculum. Competency Achievement Indicators are designed by themselves by incorporating ABCD elements, namely Audience, Behavior, Condition, and Degree. The Basic Competencies and Achievement Indicators presented cover competency content for aspects of knowledge and skills. (4) Learning objectives are presented by incorporating elements of the approach and methods used to achieve the goals and aspects of attitudes that must be considered by students while achieving learning objectives. In addition, learning objectives are not only related to the achievement of the material in accordance with the demands of the curriculum, but also must be able to meet the needs of students and their use in everyday life (Hidayah, Martani, \& Supartono, 2021). (5) The subject matter consists of three main groups, namely material for regular classes, remedial classes, and enrichment classes. For regular classes, the subject matter is grouped into four parts, namely: factual, conceptual, procedural, and metacognitive. (6) Learning methods are grouped into three parts, namely: approaches, learning models, and methods used. (7) Learning media consists of the media used and the tools/materials needed during learning. (8) Learning resources that can be used by 
5208 The Strategy of Observing, Imitation, and Modification in The Preparation of Lesson Plan in Microteaching Practice - Dina Ramadhanti, Diyan Permata Yanda

DOI: https://doi.org/10.31004/edukatif.v3i6.1664

students. The presentation of learning resources is adjusted to the rules of writing a bibliography. (9) The learning steps are adjusted to the selected learning model according to the learning objectives. This section consists of three parts, namely: preliminary activities, core activities, and closing activities. In the preliminary activity section, the teacher orients, provide motivation, and provides learning references to be implemented. In the core activity section, learning scenarios are arranged according to the syntax of the chosen learning model by integrating 21st Century skills, namely: literacy activities, critical thinking, problem-solving, collaboration, collaboration, communication. In the closing activity, there are activities carried out by teachers and students. (10) Assessment includes assessments for regular classes consisting of assessments of attitudes, knowledge, and skills, for remedial classes, and for enrichment classes. Attitude assessment can be in the form of student activity journals that can be observed during learning. Knowledge assessment can be in the form of choice tests and essays to test students' understanding of the theoretical concepts given. Skills assessment can be in the form of a performance test equipped with an assessment rubric, in the form of an analytic rubric, or a holistic rubric.

By applying the strategy of observing, imitation, and modification, students-teachers can present lesson plans according to the examples provided. They can achieve the eight assessment criteria given, namely: the completeness of the learning plan components, the ability to formulate indicators of competency achievement, the ability to formulate learning objectives, the ability to formulate subject matter, the ability to choose learning models or methods that are in accordance with learning objectives, the ability to choose media and learning resources, the ability to design learning steps according to learning methods and incorporate $21 \mathrm{st}$ Century learning elements, and the ability to design assessments.

From the eight assessment indicators, in general, students-teachers are able to understand and develop lesson plans well. However, students-teacher still have to continue to practice developing learning scenarios that integrate 21 st Century skills into learning steps according to the learning model used. In addition, studentteacher must also continue to practice compiling assessments of attitudes, knowledge, and skills as a means of evaluating students' abilities and skills. A well-planned evaluation tool will be able to measure the abilities and skills of students (Ramadhanti, Yanda, Ghazali, Hasanah, \& Harsiati, 2019). In addition, the learning outcomes of the student-teacher can not be separated from the strategy of observing, imitation, and modification used. Student-teacher can learn from the given object, namely the 21 st Century learning plan that has been prepared in accordance with the 21 st Century skills.

\section{The Effect of Observing, Imitation, and Modification Strategies on Microteaching}

In the following, the results of data analysis using pair sample t-test are presented to investigate whether learning outcomes after using the observing, imitation, and modification strategy are better than before using the observing, imitation, and modification strategy in Microteacing learning, especially in preparation a lesson plan. The results of data analysis using the pair sample t-test are presented in Tables 3, 4, and 5 below.

Table 3

Paired Sample Statistics

\begin{tabular}{|c|c|c|c|c|c|}
\hline & & Mean & $\mathbf{N}$ & $\begin{array}{l}\text { Std. } \\
\text { Deviation }\end{array}$ & $\begin{array}{l}\text { Std. Error } \\
\text { Mean }\end{array}$ \\
\hline Pair & Pretest & 75.8636 & 22 & 6.12019 & 1.30483 \\
\hline 1 & Postest & 84.5455 & 22 & 4.38316 & 0.93449 \\
\hline
\end{tabular}

Table 3 above informs the average pretest and posttest scores. The average value of the pretest is 75.86 while the average value of the posttest is 84.55 . Thus, the posttest average value is higher than the pretest average value with a ratio of 8.68 points. 
5209 The Strategy of Observing, Imitation, and Modification in The Preparation of Lesson Plan in Microteaching Practice - Dina Ramadhanti, Diyan Permata Yanda

DOI: https://doi.org/10.31004/edukatif.v3i6.1664

Table 4

Paired Samples Correlations

\begin{tabular}{|c|c|c|c|c|}
\hline & & $\mathbf{N}$ & Correlation & Sig. \\
\hline Pair & Pretest \& Postest & 22 & .642 & .00 \\
\hline
\end{tabular}

Table 4 above informs the correlation between pretest and posttest data. The correlation value between the pretest and posttest values is 0.642 . This shows that there is a very strong positive correlation between the pretest and posttest scores.

Table 5

Paired Samples Test

\begin{tabular}{|c|c|c|c|c|c|c|c|}
\hline \multicolumn{5}{|c|}{ Paired Differences Pretest-Postest } & \multirow{3}{*}{$\mathbf{t}$} & \multirow{3}{*}{ df } & \multirow{3}{*}{$\begin{array}{l}\text { Sig. (2- } \\
\text { tailed) }\end{array}$} \\
\hline \multirow[t]{2}{*}{ Mean } & \multirow[t]{2}{*}{ Std. Deviation } & \multirow{2}{*}{$\begin{array}{l}\text { Std. } \\
\text { Error } \\
\text { Mean }\end{array}$} & \multicolumn{2}{|c|}{$\begin{array}{l}\text { 95\% Confidence } \\
\text { Interval of the } \\
\text { Difference }\end{array}$} & & & \\
\hline & & & Lower & Upper & & & \\
\hline-8.68 & 4.71 & 1.005 & -10.77 & -6.591 & -8.64 & & .000 \\
\hline
\end{tabular}

Table 5 above informs the results of the significance test of the pretest and posttest data. The significance value is 0.000 . The basis for decision making to determine which learning is better before and after using the observing, imitation, and modification strategy, namely: If the significance value (2-tailed) < 0.05 then there is a significant difference between the learning outcomes before and after using the observing, imitation, and modification strategy. On the other hand, if the significance value (2-tailed) $>0.05$, there is no significant difference between the learning outcomes before and after using the observing, imitation, and modification strategy. The significance value (2-tailed) in Table 5 above is 0.000 . Thus, the significance value (2-tailed) $<0.05$. This means: there is a significant difference between learning outcomes before and after using the observing, imitation, and modification strategy. Learning outcomes after using the observing, imitation, and modification strategy are better than before using the observing, imitation, and modification strategy because on average, the posttest score is 8.68 points higher than the pretest score. The value is very high. This also means that there is a significant effect of using the observing, imitation, and modification strategy on Microteching learning, especially in the preparation of lesson plans.

The strategy of observing, imitation, and modification has proven to be effective in learning. This strategy significantly affects the learning outcomes of students-teacher. Several studies also show that the strategy of observing, imitation, and modification has proven to be effective in learning (Amalia \& Hasibuan, 2018)'(Herlina, Iswara, \& Kurniadi, 2016).

This strategy is effectively used in learning because of the process of observing and imitating who is carried out by students. They can absorb and display the lesson plans they read. This is in accordance with the concept of social learning theory, which people can generally learn through observation, imitation, and modeling (Edinyang, 2016)'(Nabavi, 2012). A person can learn from the behavior they observe. At first, they will observe the object that is the model, remember the observed behavior, and replicate the observed behavior through a modification process. With this concept, the strategy of observing, imitation, and modification developed from this social learning theory is proven to increase creativity, learning ability, and attention of students to their learning (Alshobramy, 2019).

\section{CONCLUSSION}

Good learning is created through good planning. Learning planning includes plans for the implementation of learning and plans for the evaluation tools used. In preparing the lesson plan, knowledge of the components of the lesson plan is needed. Learning plans are considered as the main key to implementing learning and being the heart for the implementation of quality learning. The practice of microteaching is carried out not only to practice basic teaching skills but also to train students-teacher to design lesson plans. 
5210 The Strategy of Observing, Imitation, and Modification in The Preparation of Lesson Plan in Microteaching Practice - Dina Ramadhanti, Diyan Permata Yanda

DOI: https://doi.org/10.31004/edukatif.v3i6.1664

Good planning is the beginning of the implementation of quality learning. Professional teachers are teachers who are able to plan and implement learning professionally. Microteaching is one of the efforts to shape students-teacher to become professional teachers starting from micro classes to getting used to teaching professionally in real classes. Therefore, supervisors in microteaching classes teach not only basic teaching skills but also learning planning skills.

\section{ACKNOWLEDGEMENTS}

The authors would like to thank the students of the 2018-C Program Studi Pendidikan Bahasa dan Sastra Indonesia who attended the Microteaching lecture as well as the subject of this research. Next to the Jurnal Edukatif: Jurnal Ilmu Pendidikan who has been willing to review and publish this article.

\section{REFERENCES}

Akman, O. (2018). The Eurasia Proceedings of Educational \& Social Sciences (EPESS) The Eurasia Proceedings of Educational Effect of Technology Assisted Micro Teaching Practices on the Perception of Technology Usage of Social Studies Teacher Candidates. \& Social Sciences (EPESS), 9, 299-302. Retrieved from www.isres.org

Ali, A. (2021). Concept of Micro-Teaching and the Role of Supervisor in Micro-Teaching, 5(1), 1-11.

Alshobramy, H. A. (2019). The Effectiveness of Bandura's Social Learning Theory in Learning English Speaking Skill Among Secondary School EFL Students. International Journal of Vocational and Technical Education Research, 5(5), 11-23.

Amalia, N., \& Hasibuan, S. H. (2018). The Effect of Observing Imitation of Modification (ATM) Strategy Learning By Using Video Media On The Student's Ability To Read Poetry By Class Vii Junior High School At MTs. Profunedu, 3(2018-11-30), 7-9. Retrieved from http://repository.profunedu.id/index.php/proceeding/article/view/32

Apling, M., \& Haryani, S. (2019). The Analysis of Microteaching in Improving Teaching Skill of Pre-Service Physics Teachers. Journal of Innovative Science Education, 8(1), 344-348.

Bilen, K. (2015). Effect of Micro Teaching Technique on Teacher Candidates' Beliefs regarding Mathematics Teaching. Procedia - Social and Behavioral Sciences, 174, 609-616.

https://doi.org/10.1016/j.sbspro.2015.01.590

d'Alessio, M. A. (2018). The Effect of Microteaching on Science Teaching Self-Efficacy Beliefs in Preservice Elementary Teachers. Journal of Science Teacher Education, 29(6), 441-467. https://doi.org/10.1080/1046560X.2018.1456883

Dorovolomo, J., Phan, H. P., \& Maebuta, J. (2010). Quality lesson planning and quality delivery: Do they relate? International Journal of Learning, 17(3), 447-456. https://doi.org/10.18848/14479494/CGP/v17i03/46955

Edinyang, S. D. (2016). The Significance of Social Learning Theories in the Teaching of Social Studies Education. International Journal of Sociology and Anthropology Research, 2(1), 40-45.

Fryling, M. J., Johnston, C., \& Hayes, L. J. (2011). Understanding Observational Learning: An Interbehavioral Approach. The Analysis of Verbal Behavior, 27(1), 191-203. https://doi.org/10.1007/bf03393102

Greer, R. D., Dudek-Singer, J., \& Gautreaux, G. (2006). Observational learning. International Journal of Psychology, 41(6), 486-499. https://doi.org/10.1080/00207590500492435

Hendrizal, Wahyuni, S., \& Desmariani, E. (2016). Kompetensi Guru SD IT Adzkia Padang. JURNAL EDUCATIVE: Journal of Educational Studies, 1(2), 110-120.

Herlina, R., Iswara, P. D., \& Kurniadi, Y. (2016). Penerapan Metode ATM (Amati, Tiru, dan Modifikasi) 
5211 The Strategy of Observing, Imitation, and Modification in The Preparation of Lesson Plan in Microteaching Practice - Dina Ramadhanti, Diyan Permata Yanda

DOI: https://doi.org/10.31004/edukatif.v3i6.1664

Berbantuan Media Audio Visual untuk Meningkatkan Keterampilan Membaca Puisi. Jurnal Pena Ilmiah, 1(1), 881-890. https://doi.org/10.23819/pi.v1i1.2878

Hidayah, S. N., Martani, W., \& Supartono, W. (2021). Accommodating Stakeholder's Voice in the Curriculum Development in an Indonesian Higher Education Institution. JURNAL EDUCATIVE: Journal of Educational Studies, 6(1), 18-31.

Iswantir, M., \& Sesmiarni, Z. (2021). The Evaluation of Online Learning in Micro Teaching Course in Tarbiyah and Teacher Training Faculty IAIN Bukittinggi. Journal of Physics: Conference Series, 1779(1), 1-7. https://doi.org/10.1088/1742-6596/1779/1/012044

Kant, R. (2017). Microteaching: Attitude and Perception of Students and Teacher Educators. International Journal of Current Research, 9(9), 58385-58388.

Khikmah, N., Lovia, N., Zahro, F., \& Azizah, F. N. (2021). Pemanfaatan Google Classroom dalam Praktik Microteaching Pembelajaran Fiqih MI bagi Mahasiswa PGMI UIN Walisongo Semarang, 4(1), 237 246.

Mahmud, I. (2013). Micro Teaching to Improve Teaching Method: An Analysis on Students' Perspectives. IOSR Journal of Research \& Method in Education (IOSRJRME), 1(4), 69-76. https://doi.org/10.9790/7388-0146976

Munthe, E., \& Conway, P. F. (2017). Evolution of Research on Teachers' Planning: Implications for Teacher Education. The SAGE Handbook of Research on Teacher Education, (July), 836-852. https://doi.org/10.4135/9781526402042.n48

Nabavi, R. T. (2012). Bandura's Social Learning Theory \& Social Cognitive Learning Theory, (January 2012), 1-24.

Novrianti. (2016). Teknik Pengembangan dan Evaluasi Program Pembelajaran Berbasis Multmedia Interaktif. JURNAL EDUCATIVE: Journal of Educational Studies, 1(1), 45-60.

Nurdin, S. (2016). Guru Profesional dan Penelitian Tindakan Kelas. JURNAL EDUCATIVE: Journal of Educational Studies, 1(1), 1-12.

R. Kimaro1, A., Mhagama, M., \& Onyango, D. (2021). The Influence of Micro-Teaching in Enhancing Teaching Competences of Pre-Service Teachers: A Case of Saint Augustine University of Tanzania. East African Journal of Education and Social Sciences, 2(Issue 1 (January to March 2021)), 11-22. https://doi.org/10.46606/eajess2021v02i01.0061

Ramadhanti, D., Yanda, D. P., Basri, I., \& Abdurahman. (2020). Modul Pembelajaran Menulis Cerpen sebagai Penunjang Pembelajaran Jarak Jauh untuk SMP (A Learning Module of Short Story Writing as a Tool of Distance Learning for Junior High School). SALINGKA, 17(2), 146-163.

https://doi.org/10.26499/salingka.v17i2.433

Ramadhanti, D., Yanda, D. P., Ghazali, A. S., Hasanah, M., \& Harsiati, T. (2019). Development of Explanatory Text Writing Evaluation Tools Based on a Process Approach (Pengembangan Alat Evaluasi Menulis Teks Eksplanasi Berbasis Pendekatan Proses). Jurnal Gramatika: Jurnal Penelitian Pendidikan Bahasa Dan Sastra Indonesia, 5(2), 194-210. https://doi.org/https://doi.org/10.22202/JG.2019.V5i2.3445

Ramanathan, R., Narayanan, S., Mutalik, A., Shanmugam, J., Padmavathy, L., Vaishnavi, C., \& Kathiravan, R. (2021). Impact of Microteaching in Enhancing Teaching Skills of Medical College Faculty. Journal of Advances in Education and Philosophy, 5(6), 160-164. https://doi.org/10.36348/jaep.2021.v05i06.003

Rasmawan, R. (2021). Pengembangan Instrumen Microteaching Berdasarkan Pembelajaran Abad Ke-21. Edukasi: Jurnal Pendidikan, 19(1), 31. https://doi.org/10.31571/edukasi.v19i1.2348

Remesh, A. (2013). Microteaching, an efficient technique for learning effective teaching. Journal of Research in Medical Sciences, 18(2), 158-163. 
5212 The Strategy of Observing, Imitation, and Modification in The Preparation of Lesson Plan in Microteaching Practice - Dina Ramadhanti, Diyan Permata Yanda

DOI: https://doi.org/10.31004/edukatif.v3i6.1664

Suryani, F. B., \& Rismiyanto, R. (2021). The Effect of Microteaching Lesson Study on the Beliefs of EFL Student Teachers. EduLite: Journal of English Education, Literature and Culture, 6(1), 1. https://doi.org/10.30659/e.6.1.1-9

Tatminingsih, S. (2020). Teaching Practice Patterns in ECE Teacher Program in Distance Education in Indonesia. Jurnal Obsesi : Jurnal Pendidikan Anak Usia Dini, 5(1), 857-868. https://doi.org/10.31004/obsesi.v5i1.599

Turney, C. (1970). Micro-Teaching - A Promising Innovation in Teacher Education. Australian Journal of Education, 14(2), 125-141. https://doi.org/10.1177/000494417001400202

Wahyudi, D., \& Sari, A. (2016). Penggunaan Media, Variasi, dan Umpan Balik dalam Proses Pembelajaran untuk Mengoptimalkan Hasil Belajar Siswa. JURNAL EDUCATIVE: Journal of Educational Studies, $1(2), 86-95$.

Wang, J. (2021). The Influence of Micro-teaching on Teaching Abilities of Students Majoring in Physical Education in Physical Schools. E3S Web of Conferences, 251.

https://doi.org/10.1051/e3sconf/202125103077 